\title{
Pandemic spotlight on urban water quality
}

\author{
Dennis W. Hallema ${ }^{1 *}\left(\mathbb{D}\right.$, François-Nicolas Robinne ${ }^{2}$ and Steven G. McNulty ${ }^{3}$
}

\begin{abstract}
Surface water improvements associated with the COVID-19 economic slowdown illustrate environmental resiliency and societal control over urban water quality.
\end{abstract}

\section{Correspondence}

Reliable urban water supplies are essential to economic activity and depend on the continuous availability of clean water delivered by rivers (Haddeland et al. 2014). Estimates indicate that urban water demand may increase up to $80 \%$ by 2050 (Flörke et al. 2018); however, the ability to meet the increasing demand varies locally. Critical factors are the level of accessibility (Livesley et al. 2016), water treatment infrastructure (Krueger et al. 2019), and impacts from recurring summer drought, wildfires (Hallema et al. 2018), and urbanization (Livesley et al. 2016). Recent observations of rapid environmental recovery add a new dimension to the debate, namely that of the potential impacts of COVID-19 pandemic responses on surface water quality.

Most poignant however are the improvements in air quality. Satellite data are showing significant reductions of $\mathrm{NO}_{2}$ (nitrogen dioxide) over major cities in China, Europe, the USA, and India following lockdowns enforced to slow the spread of SARS-CoV-2 (NASA Earth Observatory 2020) (Fig. 1). In Venice, Italy, canal water appeared visibly clearer following the lockdown (but not necessarily cleaner). Presumably, reduced boat traffic on the canals resulted in lower sediment concentrations near the water's surface (Link 2020).

Notwithstanding the disastrous effects on public health and economic welfare, these cases are remarkable illustrations of the highly dynamic nature of environmental systems driven by natural processes like the wind and tides. As post-pandemic water quality data becomes

\footnotetext{
* Correspondence: dwhallem@ncsu.edu

${ }^{1}$ Department of Forestry and Environmental Resources, North Carolina State University, 3041 East Cornwallis Road, Research Triangle Park, NC 27709, USA Full list of author information is available at the end of the article
}

available, we can also expect to see examples of temporarily improved surface water quality in urban areas. The nature and extent of these improvements will depend on the level of urbanization (regional and distribution within the watershed), climate (predominant wind direction and precipitation), and physical characteristics of the watershed (topography and infiltration dynamics of the soil). The respective contributions of groundwater and storm drainage to river flow can indicate how reduced input of contaminants affects surface water quality. Because upstream portions of watersheds often have a lower level of human disturbance, this is where large basins tend to exhibit a higher level of resilience (Hallema et al. 2019).

Under an economic slowdown scenario, headwaters hundreds of kilometers away from urban areas will experience reduced deposition from nonpoint sources of pollution (regionally produced nitrogen dioxide, sulfur dioxide, ammonia, and other gaseous pollutants). For example, given the reduction in nitrogen dioxide concentrations observed over Eastern China, Europe, the Northeastern United States, and India (Fig. 1), this is where urban surface water quality may start showing signs of temporary recovery. Downstream surface waters may also receive less input from both point sources of pollution (e.g., industrial sites) and nonpoint sources (e.g., motorized traffic), as the lockdowns continue. Under an economic worst-case scenario, input from other major nonpoint sources, like mining and agriculture, can potentially decline due to ripple effects created by a slowdown of the global economy. The effects of reduced point source inputs on surface water quality might become evident within a matter of months while 

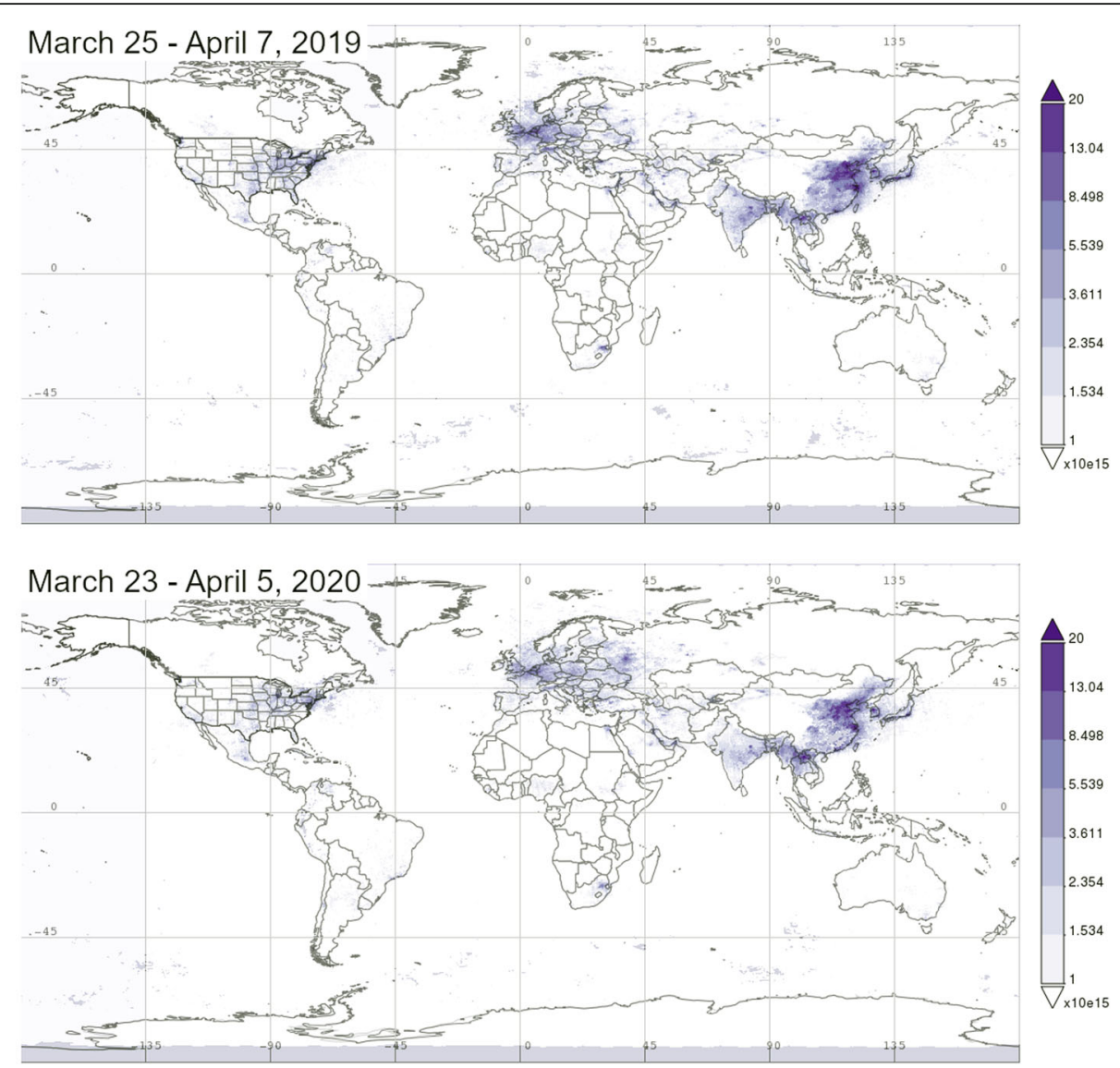

Fig. $1 \mathrm{NO}_{2}$ (nitrogen dioxide) in the tropospheric column ( $\mathrm{mol} \mathrm{cm}{ }^{-2}$ ) for the first 14 days of spring 2019 (top) and 2020 (bottom), respectively, several weeks after many countries worldwide initiated lockdowns [maps generated with the Giovanni online tool (Prados et al. 2010) using data from the Ozone Monitoring Instrument on NASA's Aura satellite, $30 \%$ cloud screened, daily $0.25^{\circ}$ resolution]

the effect of reduced nonpoint source inputs could take much longer to measure.

Given the frequent occurrence of urban water crises, it is critical to document how COVID-19 pandemic response management affects natural processes and surface water quality in the short term. It is equally important to determine how we can better optimize the natural function of water supply areas (Sun et al. 2018) once economic recovery is underway. The current challenge, though, is that economic sectors and industries that contribute to pollution (e.g., energy, consumer, pharmaceutical, and other industries) receive little incentive to promote urban water quality beyond what the law requires. They are chiefly evaluated in terms of total returns to the shareholders; however, an important collateral benefit of economic performance is the creation of jobs and public wealth (i.e., taxation revenue). To improve the sustainability of water supplies and cover the associated cost, it will be necessary for the public, by way of governance, to improve laws and direct public wealth toward outcomes that simultaneously support environmental and economic goals (Claassen et al. 2018).
There are very few positive aspects to be derived from the current public health emergency. The environmental responses to the economic slowdown emphasize in the first place the negative effect of humans on their environment. However, they are also a reminder that society has the ability to improve urban water quality in normal times, provided we make a conscious decision and concerted effort to create the conditions needed to reach that goal.

\section{Abbreviations}

COVID-19: Coronavirus disease 2019; NASA: National Aeronautics and Space Administration; SARS-CoV-2: Severe acute respiratory syndrome coronavirus 2

\section{Acknowledgements}

Not applicable.

\section{Authors' contributions}

DWH and FNR analyzed and interpreted the data and wrote the manuscript. SGM edited the manuscript. All authors have read and approved the final manuscript.

\section{Funding}

DWH receives funding from the U.S. Fish and Wildlife Service and USDA Forest Service. FNR receives funding from Global Water Futures through the Boreal Water Futures project. SGM receives funding from the USDA Forest 
Service and USDA Climate Hubs. Opinions are those of the authors and do not necessarily reflect the policies and views of the US Government.

\section{Availability of data and materials}

Data are publicly accessible via NASA Earthdata's Giovanni web interface, https://giovanni.gsfc.nasa.gov/.

\section{Ethics approval and consent to participate}

Not applicable.

\section{Consent for publication}

Not applicable.

\section{Competing interests}

The authors declare no competing interests.

\section{Author details}

${ }^{1}$ Department of Forestry and Environmental Resources, North Carolina State University, 3041 East Cornwallis Road, Research Triangle Park, NC 27709, USA. ${ }^{2}$ Canadian Partnership for Wildland Fire Science, Department of Renewable Resources, University of Alberta, 751 General Services Building, Edmonton, AB T6G 2H1, Canada. ${ }^{3}$ Eastern Forest Environmental Threat Assessment Center, Southern Research Station, U.S. Department of Agriculture Forest Service, Research Triangle Park, NC 27709, USA.

Received: 21 April 2020 Accepted: 24 April 2020

Published online: 06 May 2020

\section{References}

Claassen M, Vira B, Xu J, Gyawali D, Martin-Ortega J, Pol PO, Creed IF, Ellison D, McNulty SG, Archer ERM (2018) Current and future perspectives on forestwater goods and services. In: Creed I, van Noordwijk M (eds) Forest and water on a changing planet: vulnerability, adaptation and governance opportunities: a global assessment report, vol 38. IUFRO World Series, Vienna, pp 101-118

Flörke M, Schneider C, McDonald RI (2018) Water competition between cities and agriculture driven by climate change and urban growth. Nat Sustain 1(1):51-58

Haddeland I, Heinke J, Biemans H, Eisner S, Flörke M, Hanasaki N, Konzmann M, Ludwig F, Masaki Y, Schewe J, Stacke T (2014) Global water resources affected by human interventions and climate change. Proc Natl Acad Sci U S A 111(9):3251-3256

Hallema DW, Kinoshita AM, Martin DA, Robinne F-N, Galleguillos M, McNulty SG, Sun G, Singh KK, Mordecai RS, Moore PF (2019) Fire, forests and city water supply. Unasylva 251(70):58-66 http://www.fao.org/documents/card/en/c/ca6 842en

Hallema DW, Sun G, Caldwell PV, Norman SP, Cohen EC, Liu Y, Bladon KD, McNulty SG (2018) Burned forests impact water supplies. Nat Commun 9: 1307 https://doi.org/10.1038/s41467-018-03735-6

Krueger E, Rao PSC, Borchardt D (2019) Quantifying urban water supply security under global change. Glob Environ Chang 56:66-74

Link D (2020) Fact check: COVID-19 crisis has not created decreased long-term human environmental impact. USA Today. Mar 25. https://www.usatoday. com/story/news/factcheck/2020/03/25/fact-check-coronavirus-crisisbenefiting-environment/2908300001/ Viewed 17 Apr 2020.

Livesley SJ, McPherson EG, Calfapietra C (2016) The urban forest and ecosystem services: impacts on urban water, heat, and pollution cycles at the tree, street, and city scale. J Environ Qual 45(1):119-124

NASA Earth Observatory (2020). Airborne nitrogen dioxide plummets over China. https://www.earthobservatory.nasa.gov/images/146362/airborne-nitrogendioxide-plummets-over-china Viewed 17 Apr 2020.

Prados Al, Leptoukh G, Lynnes C, Johnson J, Rui H, Chen A, Husar RB (2010) Access, visualization, and interoperability of air quality remote sensing data sets via the Giovanni online tool. IEEE J Select Topics Appl Earth Observ Remote Sensing 3(3):359-370

Sun G, Hallema DW, Asbjornsen H (2018) Preface for the article collection "Ecohydrological processes and ecosystem services". Ecol Process 7:8. https:// doi.org/10.1186/s13717-018-0120-1

\section{Publisher's Note}

Springer Nature remains neutral with regard to jurisdictional claims in published maps and institutional affiliations.

\section{Submit your manuscript to a SpringerOpen ${ }^{\circ}$ journal and benefit from:}

- Convenient online submission

- Rigorous peer review

- Open access: articles freely available online

- High visibility within the field

- Retaining the copyright to your article

Submit your next manuscript at $\boldsymbol{\nabla}$ springeropen.com 